Journal of Animal and Veterinary Advances 9 (23): 2890-2899, 2010

ISSN: $1680-5593$

(C) Medwell Journals, 2010

\title{
Histopathological and Genotoxic Effects of Pollution on Anguilla anguilla in the Gediz River (Turkey)
}

\author{
${ }^{1}$ Sukran Yildiz, ${ }^{1}$ Beyhan Gurcu, ${ }^{2}$ Yucel Basimoglu Koca and ${ }^{2}$ Serdar Koca \\ ${ }^{1}$ Deparment of Biology, Faculty of Science and Art, Celal Bayar University, Manisa, Turkey \\ ${ }^{2}$ Deparment of Biology, Faculty of Science and Art, Adnan Menderes University, Aydin, Turkey
}

\begin{abstract}
The aim of the present study was to determine heavy metal accumulation in water, sediment and some tissues of Anguilla anguilla along with determining histopathological and genotoxic effects of accumulation on these tissues by using light microscopy. Water, sediment and fish tissue samples taken from different sites of 3 different study areas were studied and the order of accumulation of metals was $\mathrm{Fe}>\mathrm{Pb}>\mathrm{Mn}>\mathrm{Co}>\mathrm{Zn}>\mathrm{Ni}>$ $\mathrm{Cr}>\mathrm{Cu}>\mathrm{Cd}$ in water, $\mathrm{Fe}>\mathrm{Co}>\mathrm{Mn}>\mathrm{Pb}>\mathrm{Zn}>\mathrm{Ni}>\mathrm{Cr}>\mathrm{Cu}>\mathrm{Cd}$ in sediment and $\mathrm{Cd}>\mathrm{Mn}>\mathrm{Cu}>\mathrm{Cr}>\mathrm{Ni}>\mathrm{Fe}>\mathrm{Zn}>\mathrm{Co}>\mathrm{Pb}$, $\mathrm{Cd}>\mathrm{Pb}>\mathrm{Ni}>\mathrm{Cr}>\mathrm{Mn}>\mathrm{Cu}>\mathrm{Fe}>\mathrm{Co}>\mathrm{Zn}$ and $\mathrm{Cr}>\mathrm{Ni}>\mathrm{Zn}>\mathrm{Cd}>\mathrm{Pb}>\mathrm{Mn}>\mathrm{Cu}>\mathrm{Fe}>\mathrm{Co}$ in liver, muscle and gill of fish, respectively. In histopathological studies, a decrease in the length of primary and secondary lamellae of gills, fusion in secondary lamellae, cellular proliferation, clavate lamellae formation and necrosis were observed. In liver tissue, dilation of sinusoid, increase in the number of erythrocytes, ruptured hepatocytes, decrease in glycogen accumulation and vacuolization were observed. In muscle tissue, necrosis, cellular dissolution and loss of striatation in muscle fibers were found. It was observed that pollution of water had no genotoxic effect on Anguilla anguilla.
\end{abstract}

$\underline{\text { Key words: } \text { Bioaccumulation, water, sediment, fish, histopatology, micronucleus }}$

\section{INTRODUCTION}

Environmental pollution came into being when urban life started and has increased parallel to the industrial development since then. Especially in the second half of the 20th century, increasing environmental pollution due to rapid population growth caused natural resources to become more polluted as a result of which destruction of ecosystem became a much more acute issue. As the aquatic environment that forms a part of the ecosystem is used for discharge and disposal of used water and other wastes, it has become the most polluted part when air and soil are also considered.

These pollutant elements affecting the natural balance can be grouped as follows: Organic materials, industrial wastes, petroleum derivatives, artificial agricultural fertilizers, detergants, radioactivity, pesticides, inorganic salts, artificial organic chemical materials and waste heat. According to this classification, heavy metals are among industrial wastes and some pesticides and they have reached to a level threatening the ecological balance (Gumgum et al., 1994; Solomons and Forstner, 1984; Leland et al., 1978; Hammond and Beliles, 1980). Although, heavy metals are trace components of aquatic environment, their natural levels and accumulations in organisms can be different. The term heavy metal covers all the metals and metalloids in the nature. In the era, the areas of use for heavy metals are increasing parallel to the development in industry and improvement in life standards. Pest control is an important factor contributing to the increase.

Heavy metals are considered to be among important pollutants of aquatic ecosystems as they do not degrade or decompose in the nature but tend to accumulate in aquatic organisms (Veena et al., 1997; Kalay and Canli, 2000).

Heavy metals may accumulate in tissues of aquatic animals when such animals are exposed to high levels of heavy metals (Vinodhini and Narayanan, 2009).

With regard to metal pollution, it is defined that gills and kidney tubules are the first organs exposed to heavy metals and gills and digestion system are the regions where heavy metals are received and accumulated while gills and liver are the regions where heavy metals are stored (Thophon et al., 2003; Olojo et al., 2005). It is known that heavy metals have toxic effects even at places away from the source of pollution as they have the ability of biological accumulation (Barlas, 1997). Toxic

Corresponding Author: Sukran Yildiz, Department of Biology, Faculty of Science and Art, Celal Bayar University, Manisa, Turkey 
substances may knock down immune system, reproduction system, nervous system and endocrine system in animals and these effects can be at organ, tissue and cell level (Geeraerts and Belpaire, 2009). Fish are susceptible to acute and chronic environmental changes and they show a classical stress response.

This stress response covers the changes in plasma glucocorticoids and cathecolamines. Environmental changes may cause hypoxia, metabolic acidosis and alkalosis, hypotension and hypoglysemia (Wendelaar, 1997; Fabbri et al., 1998). Gill tissue is an organ having a large surface and separating blood from water in fish and is very susceptible to changes in concentrations of the variables (ph, salinity, temperatue, ammonia, heavy metals etc.) in the environment. These variables affect the structural integrity of the gill and cause morphological changes.

For this reason, gills are thought to be indicators of water pollution (Ortiz et al., 1999; Bhagwant and Elahee, 2002; Wood et al., 2002; Koca et al., 2005, 2008). Liver plays an important role in protecting inner homeostasis in vertebrae. The higly dynamic nature of the liver and its regulation in many metabolic and physiological processes makes this organ a valuable model to study (Segner, 1998). Muscle tissue forms a major part of the body weight of fish when compared to other vertebrae (Fabbri et al., 1998) and economically it is very valuable.

Histological examination of tissues is a useful method to determine both the effects of environmental variables and also types of indicators in biological survey programs. Many studies have reported that not death but major damage in organs is observed in animals that are exposed to heavy metals, Polycyclic Aromatic Hydrocarbons (PAH) and pesticides even in trace amounts.

As a result, it is known that metals accumulate on sediment surface in bentic living things, planctonic organisms and other living things through food chain and aquatic organisms and human beings are affected negatively as a result of the said accumulation. For this reason, toxicological bioaccumulation and pathological researches of metals being discharged to aquatic environments have a great importance for the presence of biological life and protection of nature (Davies et al., 1991; Srivastava et al., 1994; Ankley et al., 1996; Klavins et al., 2000; Gonzales et al., 2000; Singh, 2001 ). In aquatic organisms, various cytogenetic methods such as chromosomal aberrations, sister chromatid exchange and micronucleus formation are used to test genotoxicity of chemicals (Al-Sabti ,1986). Micronucleus test is a commonly used method in fish species as it is a simple, reliable and sensitive test (Jiraungkoorskul et al., 2007). Micronucleus is composed of small chromatic fragments generated as a result of chromosomal breakage following clastogenic effect and full chromosomes not migrating at anaphase as a result of a aneugenic effect (Heddle et al., 1991).

The efficacy of this test system as an indicator of structural genomic damage has long been established and micronucleus test has been used as a measure of genotoxic stress in fish under both laboratory and field conditions (Al-Sabti, 2000; Grisolia and Starling, 2001; Cavas and Ergene-Gozukara, 2003; Koca et al., 2005, 2008).

\section{MATERIALS AND METHODS}

Study area: The Gediz river is $401 \mathrm{~km}$ long and lies in the west of Turkey. Its basin is $17.500 \mathrm{~km}^{2}$. It is used for irrigation, fishing and supporting dam lakes. Its pollution resources are sand and gravel mines, leather industry, residential wastes and wastes of organized industrial zones. The study was conducted in three different sites (Fig. 1):

Site 1: The area polluted mainly by downtown wastes

Site 2: Muradiye settlement area

Site 3: Menemen settlement area

Analitical procedure: The study was conducted at three stations. Using Nansen Sampler, water samples were collected from a depth of $0.5 \mathrm{~m}$ below the surface into clean polyethylene bottles. The water temperature, electrical conductivity, dissolved oxygen and $\mathrm{pH}$ were measured in situ. To acidify the samples, $1 \mathrm{~mL}$ of $0.5 \%$ $\mathrm{HNO}_{3}$ was added. Fish were killed and then kept on ice until used for laboratory tests. Approximately, $4 \mathrm{~g}$ of the epaxial muscle on the dorsal surface of the fish, the entire liver and two gill racers were dissected from each sample, washed using ice-cold distilled water, dried in filter paper, weighed, packed in polyethylene bags and frozen at $30^{\circ} \mathrm{C}$ until analysis (Bernhard, 1976).

The samples were preserved and analysed according to the American Public Health Association and the American Water Works Association standards (APHA-AWWA-WPCF, 1996) After weighing, $5 \mathrm{~mL}$ of $65 \%$ nitric acid was added to samples for digestion in a CEM Mars 5 microwave digestion system. The advantages of microwave digestion are the shorter times 


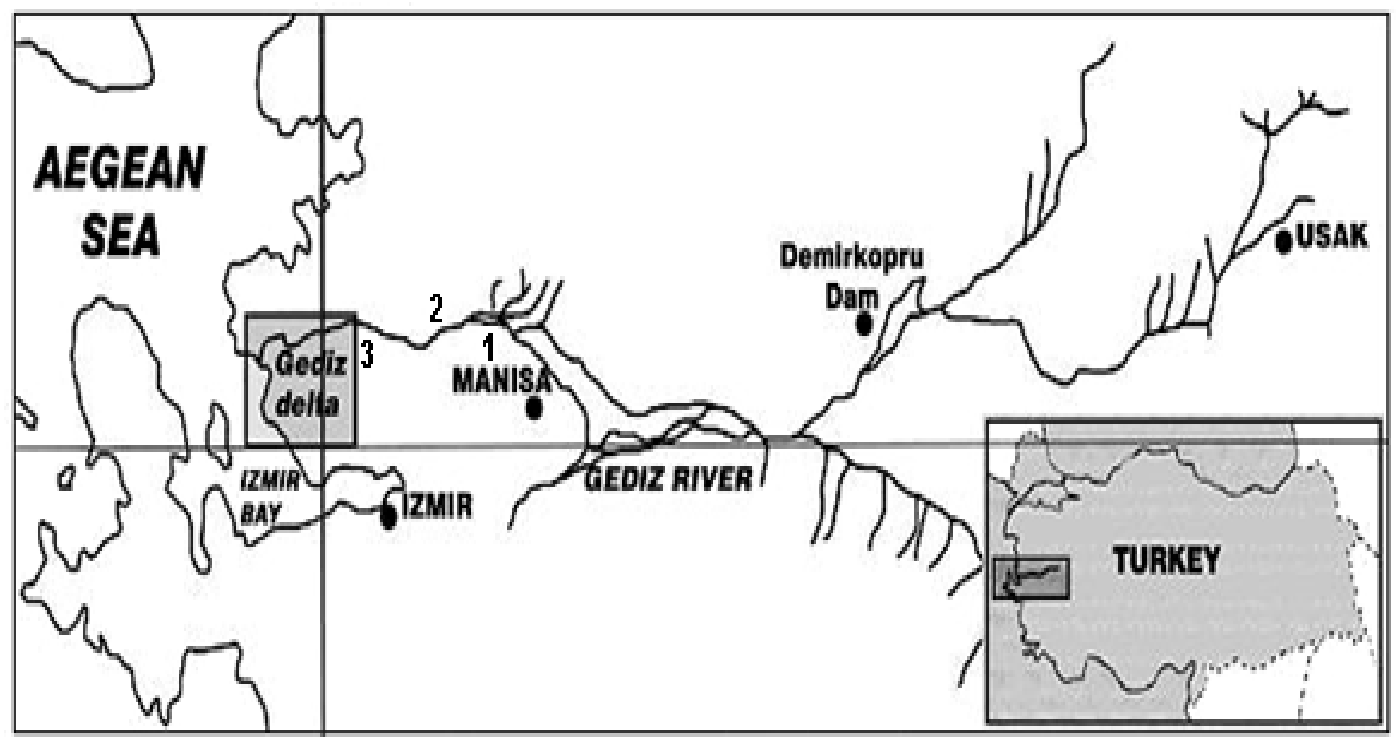

Fig. 1: Sampling sites of the Gediz river

and minimal loss of volatile compounds (Gulmini et al., 1994). After digestion, the samples were cooled down to room temperature and diluted to $25 \mathrm{~mL}$ with $2.5 \% \mathrm{HNO}$. $\mathrm{The} \mathrm{Cd}, \mathrm{Co}, \mathrm{Cu}, \mathrm{Ni}, \mathrm{Pb}, \mathrm{Mn}, \mathrm{Cr}, \mathrm{Fe}$ and $\mathrm{Zn}$ in samples were determined by means of a Varian Terra Liberty II inductively coupled plasma atomic emission spectrometer. The concentrations of heavy metals were expressed as micrograms per gram of wet weight tissue.

Histological procedures: For light microscope analyses, the gill, liver and muscle tissues from Anguila anguila were fixed in both buffered neutral formalin and SaintMarie fixative $\left(+4^{\circ} \mathrm{C}\right)$ (Tuckett and Morris-Kay, 1988), dehydrated in graded ethanol series, cleared in xylene and embedded in paraffin.

Five-micrometer-thick gill, liver and muscle tissue slices cut by means of a rotary microtome (Leica RM 2145) were dehydrated and stained with Mayer's HaematoxylinEosin ( $\mathrm{H}$ and $\mathrm{E})$, Gomori trichrom, Masson trichrom and Periodic Acid Shiff-Haematoxylin (PAS-H) stain (Bancroft and Cook, 1994). The sections were examined and photographed using an Olympus BX 51 microscope. Erythrocytes count of the eel did not show any micronuclues or nucleus abnormalities.

Preparing blood preparations forgentoxicity test: A drop of blood from gills was smeared on slide and air dried. After fixation in methanol for $20 \mathrm{~min}$ the slide was stained with a $5 \%$ Giemsa solution and mounted with entellan. Preparations were studied by a single observer. In each fish, 1000 cells were counted at $1000 \times$ magnification.

\section{RESULTS AND DISCUSSION}

Analitical result: The Gediz river is exposed to agricultural waste, industrial waste and residential waste. In the present study, it was aimed to show the pollution in Gediz river with various parameters. Physicochemical measurements would reveal heavy metal toxicity and the extent of the damage on tissue and organs of Anguilla anguilla that has been consumed. According to the results obtained form the study in the Gediz river, ammonium was found as $0.050-1.610 \mathrm{mg} \mathrm{L}^{-1}$, orthophosphate and nitrit was found as $0.010-0.58 \mathrm{mg} \mathrm{L}^{-1}$ and nitrite was found as 0.043-1.118. Other measurements on water quality are shown in Table 1.

The amounts of cadmium, cobalt, chromium, copper, iron, manganese, nickel, lead and zinc were measured in sediment, water and fish samples and mean values and standart deviations are shown in Table 2-4. Accordingly, accumulations in water, sediment, muscle, liver and gill follow the following sequences, respectively: $\mathrm{Fe}>\mathrm{Pb}>$ $\mathrm{Mn}>\mathrm{Co}>\mathrm{Zn}>\mathrm{Ni}>\mathrm{Cr}>\mathrm{Cu}>\mathrm{Cd}, \mathrm{Fe}>\mathrm{Co}>\mathrm{Mn}>\mathrm{Pb}>\mathrm{Zn}>\mathrm{Ni}>\mathrm{Cr}>$ $\mathrm{Cu}>\mathrm{Cd}, \mathrm{Cd}>\mathrm{Mn}>\mathrm{Cu}>\mathrm{Cr}>\mathrm{Ni}>\mathrm{Fe}>\mathrm{Zn}>\mathrm{Co}>\mathrm{Pb}, \mathrm{Cd}>\mathrm{Pb}>\mathrm{Ni}>$ $\mathrm{Cr}>\mathrm{Mn}>\mathrm{Cu}>\mathrm{Fe}>\mathrm{Co}>\mathrm{Zn} \quad \mathrm{Cr}>\mathrm{Ni}>\mathrm{Zn}>\mathrm{Cd}>\mathrm{Pb}>\mathrm{Mn}>\mathrm{Cu}>\mathrm{Fe}$ $>$ Co.

\section{Histological results}

Gills: A decrease in the length of primary and secondary lamella of gills (Fig. 2a, b), loss in secondary lamellae (Fig. 2b), sporadic separation in secondary lamellar epithelium, clavate lamellae formation (Fig. 2c) and accumulation in blood cells due to impaired circulation as 


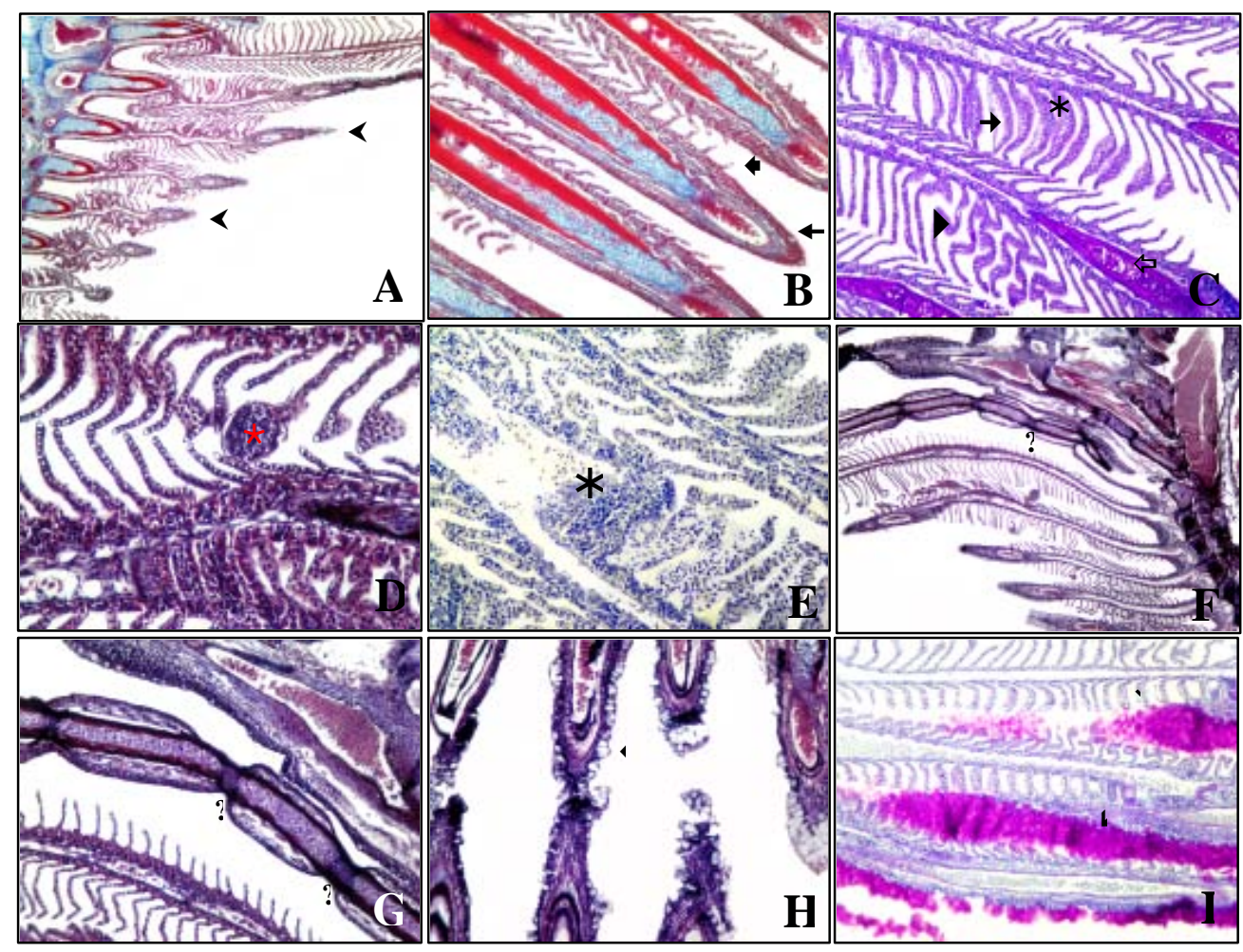

Fig. 2: The observed changes in gills of $A$. anguilla A: $>$ : Decrease of the mean length of primary lamellae, B: Decrease of the mean length of secondary lamellae, $\rightarrow$ : The lost of secondary lamellae C: $\rightarrow$ : Epithelial separating in secondary lamellae, : Clavate lamellae formation $\Rightarrow$ : Degeneration of cartilage of primer lamellae, D: $*$ : Accumulation of blood cells in dilatationed sinusoids, E: * : Hyperplasia $F, G$ : $\Delta$ : Breaking of primer lamels, $H$, $\mathrm{I}: \rightarrow$ : Mucous cells in breaking primary lamellae regions. A: Masson trichrome, $\mathrm{x} 4$, B: Masson trichrome, x10, C: PAS+H, x20, D: Gomori trichrome, x20, E: H and E, x20, F: Gomori trichrome, x4, G,H: Gomori trichrome, x20, I: $\mathrm{PAS}+\mathrm{H}, \mathrm{x} 10$

Table 1: The physical and chemical parameters of Gediz river water

\begin{tabular}{llll}
\hline Parameters & Site 1 & Site 2 & Site 3 \\
\hline Temperature $\left({ }^{\circ} \mathrm{C}\right)$ & $16 \pm 8.5$ & $14 \pm 8.4$ & $15 \pm 9.5$ \\
$\mathrm{pH}$ & $8.34 \pm 0.03$ & $8.22 \pm 0.06$ & $7.90 \pm 0.05$ \\
Electrical Conductivity (EC) & $1460 \pm 1.251$ & $1670 \pm 1.250$ & $1830 \pm 10.25$ \\
Dissolved Oxygen (DO) & $10.50 \pm 0.561$ & $11.72 \pm 0.346$ & $12.75 \pm 0.421$ \\
i- $-\mathrm{PO}_{4}{ }^{*}$ & $0.100 \pm 0.003$ & $0.300 \pm 0.002$ & $0.580 \pm 0.006$ \\
$\mathrm{NH}_{3}-\mathrm{N}$ & $1.610 \pm 0.200$ & $0.050 \pm 0.500$ & $0.089 \pm 0.010$ \\
$\mathrm{NO}_{2}-\mathrm{N}$ & $1.118 \pm 0.371$ & $1.050 \pm 0.061$ & $0.043 \pm 0.0171$ \\
$\mathrm{NO}_{3}-\mathrm{N}$ & $0.050 \pm 0.075$ & $0.040 \pm 0.461$ & $0.030 \pm 0.037$ \\
$\mathrm{~K}$ & $24.730 \pm 0.326$ & $23.60 \pm 0.361$ & $15.65 \pm 0.041$ \\
$\mathrm{Na}$ & $18.65 \pm 1.425$ & $12.55 \pm 0.375$ & $21.74 \pm 0.441$ \\
$\mathrm{Ca}$ & $3.580 \pm 0.003$ & $3.710 \pm 0.004$ & $7.850 \pm 0.006$ \\
"Chemical parameters concentration are mg L $\mathrm{L}^{+}$Sample: $\mathrm{N}: 8$
\end{tabular}

Table 2: Heavy metal concentrations of the water samples collected from

\begin{tabular}{|c|c|c|c|}
\hline Metals & Site 1 & Site 2 & Site 3 \\
\hline $\mathrm{Cd}$ & $0.005 \pm 0.002$ & $0.003 \pm 0.0002$ & $0.005 \pm 0.004$ \\
\hline Co & $0.030 \pm 0.098$ & $0.067 \pm 0.0070$ & $0.060 \pm 0.860$ \\
\hline $\mathrm{Cr}$ & $0.018 \pm 0.006$ & $0.016 \pm 0.0110$ & $0.001 \pm 0.008$ \\
\hline $\mathrm{Cu}$ & $0.008 \pm 0.006$ & $0.009 \pm 0.0130$ & $0.006 \pm 0.009$ \\
\hline $\mathrm{Fe}$ & $0.232 \pm 0.307$ & $0.308 \pm 0.3240$ & $0.279 \pm 0.379$ \\
\hline $\mathrm{Mn}$ & $0.130 \pm 0.140$ & $0.127 \pm 0.1190$ & $0.015 \pm 0.129$ \\
\hline $\mathrm{Ni}$ & $0.020 \pm 0.140$ & $0.018 \pm 0.0200$ & $0.010 \pm 0.014$ \\
\hline $\mathrm{Pb}$ & $0.143 \pm 0.095$ & $0.160 \pm 0.0820$ & $0.170 \pm 0.090$ \\
\hline$\underline{\mathrm{Zn}}$ & $0.050 \pm 0.123$ & $0.023 \pm 0.0210$ & $0.024 \pm 0.010$ \\
\hline
\end{tabular}

Table 3: Heavy metal concentrations of the sediment samples collected from Gediz rver (means $\pm \mathrm{SD}, \mu \mathrm{g} \mathrm{g}^{-1}$ )

\begin{tabular}{lrrr}
\hline Metals & \multicolumn{1}{c}{ Site 1} & \multicolumn{1}{c}{ Site 2} & \multicolumn{1}{c}{ Site 3} \\
\hline $\mathrm{Cd}$ & $2.218 \pm 2.99700$ & $4.910 \pm 0.0600$ & $2.346 \pm 2.2940$ \\
$\mathrm{Co}$ & $79.786 \pm 255.170$ & $87.601 \pm 18.116$ & $907.125 \pm 208.351$ \\
$\mathrm{Cr}$ & $35.673 \pm 11.1730$ & $84.601 \pm 22.617$ & $75.930 \pm 18.871$ \\
$\mathrm{Cu}$ & $145.506 \pm 40.7530$ & $44.211 \pm 10.001$ & $45.150 \pm 11.610$ \\
$\mathrm{Fe}$ & $489.601 \pm 218.890$ & $150.207 \pm 2.2670$ & $159.018 \pm 271.117$ \\
$\mathrm{Mn}$ & $83.490 \pm 25.7500$ & $519.987 \pm 81.031$ & $472.572 \pm 116.73$ \\
$\mathrm{Ni}$ & $116.760 \pm 45.4130$ & $94.720 \pm 21.071$ & $99.740 \pm 13.501$ \\
$\mathrm{~Pb}$ & $3.178 \pm 1.10270$ & $127.364 \pm 30.520$ & $135.251 \pm 31.613$ \\
$\mathrm{Zn}$ & $107.671 \pm 26.3610$ & $115.860 \pm 0.5843$ & $120.52 \pm 10.1140$ \\
\hline
\end{tabular}

Table 4: Heavy metal concentrations of the Anguilla anguilla samples collected from Gediz river (means $\pm \mathrm{SD}, \mu \mathrm{g} \mathrm{g}{ }^{-1}$ ) Anguilla anguilla organs

\begin{tabular}{lccc} 
& Muscle & Liver & Gill \\
\hline $\mathrm{Cd}$ & $1.2067 \pm 1.278$ & $2.071 \pm 0.0060$ & $0.0650 \pm 0.001$ \\
$\mathrm{Co}$ & $0.0276 \pm 0.007$ & $0.0375 \pm 0.017$ & $0.0355 \pm 0.010$ \\
$\mathrm{Cu}$ & $0.3761 \pm 0.045$ & $0.3030 \pm 0.074$ & $0.3545 \pm 0.004$ \\
$\mathrm{Ni}$ & $0.0781 \pm 0.006$ & $0.5950 \pm 0.021$ & $1.4851 \pm 1.236$ \\
$\mathrm{~Pb}$ & $0.0032 \pm 0.003$ & $0.9610 \pm 0.002$ & $1.0315 \pm 1.115$ \\
$\mathrm{Zn}$ & $0.0028 \pm 0.003$ & $0.0561 \pm 0.056$ & $5.355 \pm 0.360$ \\
$\mathrm{Cr}$ & $0.390 \pm 0.8710$ & $1.260 \pm 1.1500$ & $1.970 \pm 0.4500$ \\
$\mathrm{Mn}$ & $0.984 \pm 0.0710$ & $0.432 \pm 0.0150$ & $0.782 \pm 0.0062$ \\
$\mathrm{Fe}$ & $0.044 \pm 0.0290$ & $0.167 \pm 0.0740$ & $0.067 \pm 0.0060$ \\
\hline
\end{tabular}


a result of capillary dilatation (Fig. 2 d) were detected in gill tissue. Moreover, rupture of capillaries and erythrocyte releases were observed in secondary lamellae (Fig. 2e). Cartilage cells were deformed in some primary lamellar epithelium (Fig. 2c).

While integrity of secondary lamellae was impaired as a result of the necrosis and exfoliation observed in secondary lamellar epithelium, adhesion was observed due to hyperplasia (Fig. 2c, e). Some primary lamellae broke up at one or more points as a result of articulation (Fig. 2f, g) and many mucous cells were observed at the broken part (Fig. 2h, i).

Liver: In liver, altered paranchymal cell positioning, deterioration in cell membrane and necrotic areas were observed (Fig. 3a, b). In hepatocytes, intracellular glycogen storage in the form of different sizes of particles (Fig. 3c), vacuolization, alteration in the position of nucleus (Fig. 3d) and picnotic nucleus (Fig. 3a, d) were detected.

Muscle: In muscle tissue, cellular dissolution in interfibrillar area, myocyte nuclei release, necrosis (Fig. 4a) and alteration in the formation of muscle fibrils
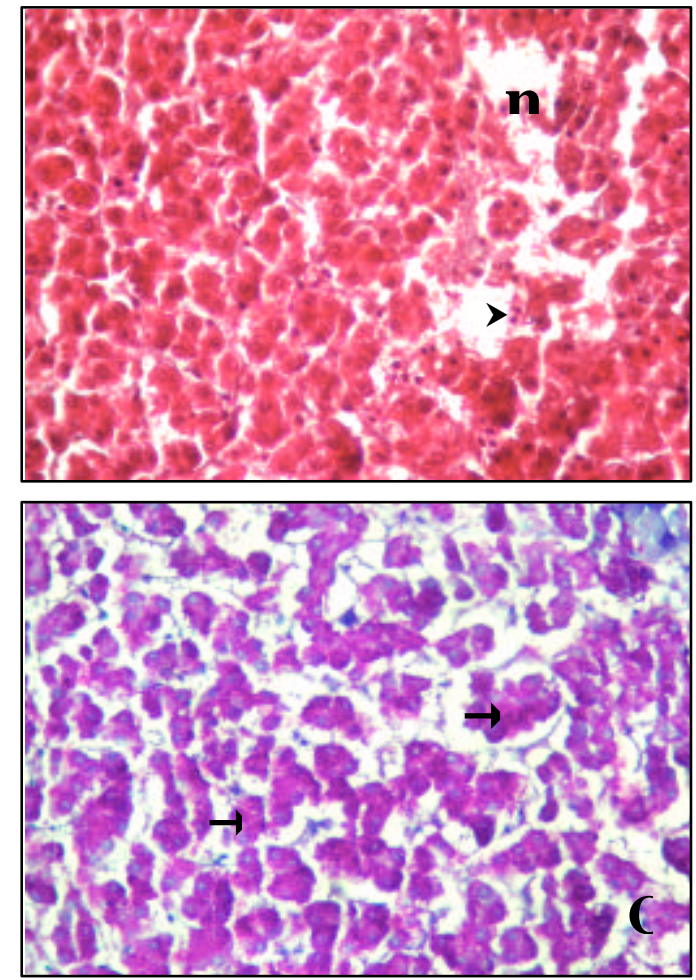

(Fig. 4b) were observed. Losses were seen in the endomysium layer around the muscle fibers (Fig. 4c). Erythrocyte counts in ells did not reveal micronucleus or any nucleus abnormality. Various researchers have reported that the Gediz river is faced with an intensive pollution risk (Akcay et al., 2003; Parlak et al., 2006). In general, nitrite has to be $<0.001 \mathrm{mg} \mathrm{L}^{-1}$ in fresh water. High levels of nitrite indicate an intensive industrial amd microbiological pollution (FAO/NHO, 1989). In the study, nitrite was found as $1.160 \mathrm{mg} \mathrm{L}^{-1}$ in site 1 where city waste waters are thought to be abundant. Excessive nitrite is the result of using intensive inorganic agricultural fertilizer.

It has to be below $1 \mathrm{mg} \mathrm{L}^{-1}$. In the present study, nitrite level varied between 0.030 and $0.050 \mathrm{mg} \mathrm{L}^{-1}$ (Table 1 ). Level of ammonium concentration has to be $<0.2 \mathrm{mg} \mathrm{L}^{-1}$ in surface water (FAO/WHO, 1989) and ammounium concentrations above the said level indicates organic pollution. In the study, it was $1.610 \mathrm{mg}$ $\mathrm{L}^{-1}$ in site 1. Orthophosphate has to be $0.30 \mathrm{mg} \mathrm{L}^{-1}$ in natural waters. In the Gediz river, its level was detected as $0.58 \mathrm{mg} \mathrm{L}^{-1}$. According to the results on water quality, site 1 where city waste water was abundant was measured as the most polluted site.
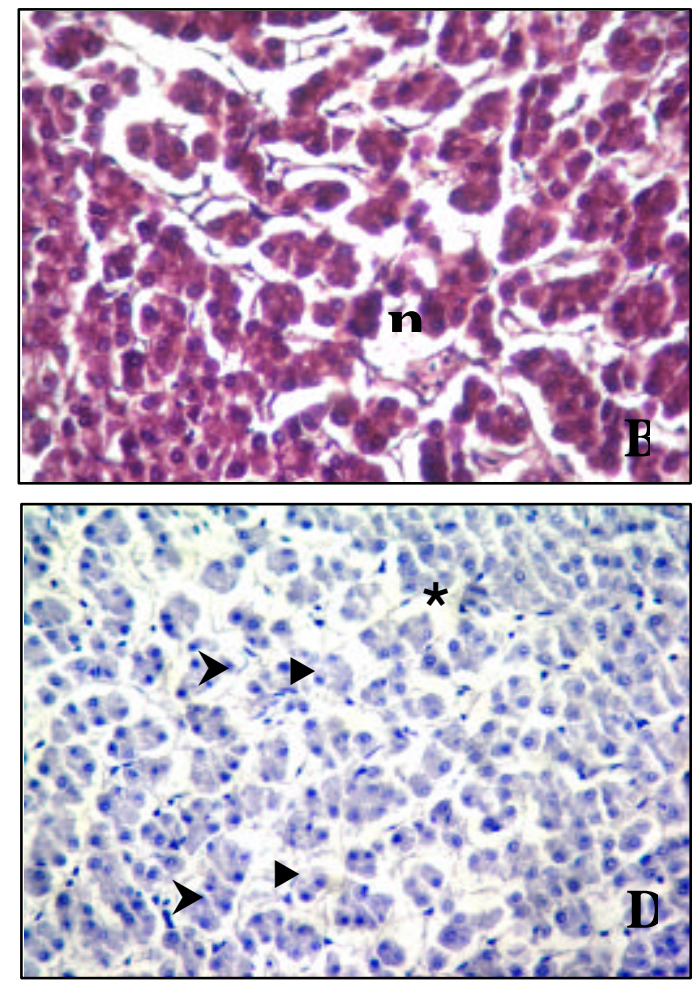

Fig. 3: The observed changes in liver of $A$. anguilla. A, B: n: Changes of cells configuration, Necrosis, C: $\rightarrow$ : Stored glycogen in hepatocytes, D: : Intracellular vacuolization, $\boldsymbol{*}$ : Hepatocytes with excantric and $>$ : Picnotic nucleus. A: Masson trichrome, $\mathrm{x} 40$, B: Gomori trichrome, $\mathrm{x} 40, \mathrm{C}$ : PAS+H, x40, D: H and E, x20 

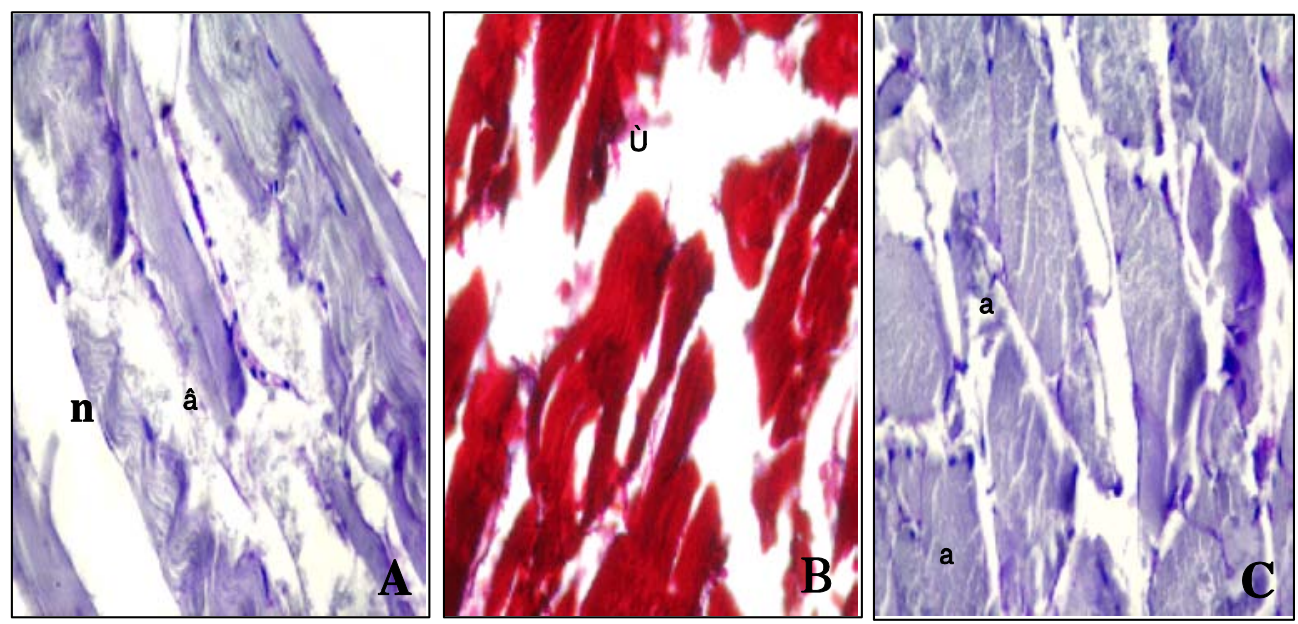

Fig. 4: The observed changes in muscle of $A$. anguilla. A: * Dissolution in sarcoplasm and releases nuclei of myocyte, n: necrosis, B: *: Disorganization of the intermyofibrillary network, $C: \Rightarrow$ : Loss of endomysium layer. A: PAS $+\mathrm{H}$, $\mathrm{x} 40$, B: Masson trichrome, $\mathrm{x} 20, \mathrm{C}: \mathrm{PAS}+\mathrm{H}, \mathrm{x} 40$

Table 5: Heavy metal concentrations in the liver and muscle in other studies

\begin{tabular}{|c|c|c|c|c|c|c|}
\hline \multirow[b]{2}{*}{ Habitat/fish/tissue } & \multirow[b]{2}{*}{ Organs } & \multicolumn{5}{|l|}{ Metals } \\
\hline & & $\mathrm{Cd}$ & $\mathrm{Cu}$ & $\mathrm{Mn}$ & $\mathrm{Pb}$ & $\mathrm{Zn}$ \\
\hline Bacuta, Spain (Usero et al., 2003) & Liver & 0.480 & 23.40 & 4.50 & 0.60 & 37.00 \\
\hline (A.anguilla) & Muscle & 0.038 & 0.70 & 14.10 & 0.09 & 11.40 \\
\hline Wildecosystems (Linde et ol., 2004) & Liver & 1.410 & 10.50 & 1.90 & - & - \\
\hline Spain (A anguilla) & Muscle & 0.060 & 0.29 & - & 0.10 & - \\
\hline $\begin{array}{l}\text { Comargue, France (Oliveira Ribeiro et al., 2005) } \\
\text { (A.conguilla) }\end{array}$ & Liver & 0.160 & 19.00 & 1.93 & 0.16 & 53.75 \\
\hline Koy ceoiz lake (Yilmaz, 2009) & Liver & 0.430 & 73.91 & 11.04 & 1.63 & 199.32 \\
\hline Turkey (A.anguilla) & Muscle & 0.160 & 2.21 & 3.14 & 1.16 & 106.71 \\
\hline FAO/WHO (1989) limits & & 0.500 & 30.00 & - & 0.50 & 40.00 \\
\hline EU limits & & 0.100 & 10.00 & - & 0.10 & - \\
\hline Range of international standards & & 0.200 & 100.00 & & $0.5-10$ & $40-100$ \\
\hline
\end{tabular}

Not including international standars

Today, heavy metals are used in many areas (Industrial etc.). These heavy metals are discharged to water and cause accumulation in sediment and aquatic living things. Consequently, increase of heavy metal in aquatic environment diminishes some very sensitive species or causes accumulation in tissues and organs of tolerant species and thus reaches to upper trophic levels. In this study, it was detected that heavy metals accumulate in sediment in different concentrations. Co, $\mathrm{Mn}$ and $\mathrm{Pb}$ concentrations were found to be the most intensive ones (Table 3). Accumulation is high in all three stations. In other studies, $\mathrm{Cr}$ concentration has been recorded as the highest one (Akcay et al., 2003; Parlak et al., 2006). In studies on tissues of Anguilla anguilla, it has been reported that accumulation is high especially in liver tissue (Oliveira Ribeiro et al., 2005, Usero et al., 2003; Yilmaz, 2009) (Table 5). While Cu and $\mathrm{Mn}$ concentrations are high in these studies, $\mathrm{Cd}$ accumulation was found to be the most intensive one in the study. In general, it has been reported that the least accumulation is in muscle tissue while the highest accumulation is in liver and gills. The study supports these findings (Melgar et al., 1997).

Toxic environmental conditions cause two types of structural changes in the tissues of living things. One of them is the direct toxic effect due to degeneration and necrosis while the other one is the defence responses of the living things (Bhagwant and Elahee, 2002). Tissues such as liver and gills are metabolically active tissues and the studies conducted indicate that these tissues accumulate high levels of heavy metals (Allen, 1995).

In fish, gills are the widest surfaces in contact with aquatic environment and thus, toxic materials cause damage in gills. These damages are edema, excessive hypertrophia and hyperplasia in lamellar epithelial cells and chloride cells. The aim of these alterations in the tissue is to minimize gill surface and consequently respiratory surface (Mallatt, 1985; Koca et al., 2005, 2008) and also to increase diffusion distance. As a consequence, respiratory function of gills is decreased 
and general health of the fish is affected which may even cause death (Thophon et al., 2003). Moreover, it has been reported that copper (Mason et al., 2002; Figueiredo-Fernandes et al., 2007), aluminum (Birchall et al., 1989), cadmium (Randi et al., 1996), lead (Olojo et al., 2005) and nickel (Athikesavan et al., 2006) cause separation in lamellar epithelium, proliferation, lamellae adhesion and lamellar aneurism.

The results obtained in the study are consistent with the literature and gills were observed to be the most affected organ.

In the study, mucous cells were observed especially at the tips of primary lamellae and between secondary lamellae. Mucous generated by these cells is a very functional material with respect to respiration, ionic and osmotic regulation, reproduction, secretion, resistance against disease, communication, nest making and protection (Shephard, 1994). Mucous secretion in fish prevents penetration of chemical toxicant and harmful materials by inceasing the diffusion distance in gills. Moreover, by causing hypoxia through making oxygene intake difficult (Nero et al., 2006), it impairs swimming capacity and behaviour of the fish. In a study, Thophon et al. (2003) reports that acute toxic action of Cd first targets gill lamellae and kidney tubules but toxic effects observed in gills is less compared to the ones in kidney and livers. Hepatocellular degeneration, vacuolization, sinusoidal dilation and red blood cell accumulation that we observed in the liver of eels (Anguilla anguilla) is similar to the findings obtained at liver exposed to $\mathrm{Cu}$ (Figueiredo-Fernandes et al., 2007) and $\mathrm{Pb}$ (Olojo et al., 2005).

In histological and cytological (TEM) studies exposed glass-eels and young yellow eels to cadmimumnitrate for a short time and they observed edema in gills, lamellae adhesion, rupture, necrosis, fibrosis in liver and disturbance in hepatocytes (Triebskorn et al., 2008). These findings are similar to the findings. In a study conducted on eels, it is shown that $\mathrm{Cd}, \mathrm{Pb}$ and $\mathrm{Cu}$ accumulate in liver while Mercury $(\mathrm{Hg})$ accumulates in muscle (Linde et al., 2004).

As eels have a long life ( $8-12$ years), pollutants may accumulate in high concentrations. Thus, even littlepolluted waters are potentially harmful (Jacques, 1990). Exposure to even trace amount of heavy metals may affect not only its physiology but also its growth, reproduction and migration.

As a result, heavy metals can be a serious ecological risk for fish, eels that have only a single reproduction chance during a long and difficult life span are getting diminished as a result of changing environmental conditions and pollution. Fish provide a suitable model for monitoring aquatic genotoxicity and wastewater quality because of their ability to metabolize xenobiotics and accumulate pollutants (Grisolia and Cordeiro, 2000). Micronucleus assay has been used successfully in various fish species (Grisolia and Starling, 2001; Koca et al., 2008; Matsumoto et al., 2006; Ergene et al., 2007).

\section{CONCLUSION}

In this study, no micronucleus formation has been observed in genotoxicity (Micronucleus test) studies conducted on some fish species caught from polluted waters. There are two possible explanations of such results: firstly, some fish species such as Genyonemus lineatus (Carrasco et al., 1990) and Phoxinus phoxsinus (Sanchez-Galan et al., 1998) have lower susceptibility to pollutants Secondly, fish have a very effective micronuclei removal system that prevents the increase in the level of micronuclei in peripheral blood (Zuniga et al., 1996; Zuniga-Gonzalez et al., 2000). In the study, not observing micronucleus and any nucleus abnormality in erythrocytes of Anguilla anguilla despite the pollution in the Gediz river suggests that these fish may have one or both of the systems stated. In some in situ studies conducted on eels, some researchers have reported that these fish (Anguilla anguilla) are not a suitable material to determine genotoxicity of water (Sanchez-Galan et al., 2001; Rodriguez-Cea et al., 2003).

\section{REFERENCES}

APHA-AWWA-WPCF, 1996. Standard Methods for the Examination of Water and Wastewater. 17th Edn., APHA-AWWA-WPCF, Washington, DC., pp: 1100.

Akcay, H., A. Oguz and C. Karapire, 2003. Study of heavy metal pollution and speciation in Buyuk Menderes and Gediz River sediments. Water Res., 37: 813-822.

Al-Sabti, K., 1986. Comparative micronucleated erythocyte cell induction in three cyprinids by five carcinogenic-mutagenic chemicals. Cytobios, 47: 147-154.

Al-Sabti, K., 2000. Chlorotriazine reactive azo red 120 textile dye induces micronuclei in fish. Ecotoxicol. Environ. Saf., 47: 149-155.

Allen, P., 1995. Chronic accumulation of cadmium in the edible tissues of Oreochromis aureus (Steindachner): Modification by mercury and lead. Arch. Environ. Contam. Toxicol., 29: 8-14.

Ankley, G.T., D.M. di Toro, D.J. Hansen and W.J. Berry, 1996. Technical basis and proposal for deriving sediment quality criteria for metals. Environ. Toxicol. Chem., 15: 2055-2066. 
Athikesavan, S., S. Vincent, T. Ambrose and B. Velmurugan, 2006. Nickel induced histopathological changes in the different tissues of freshwater fish, Hypophthalmichthys molitrix (Valenciennes). J. Environ. Biol., 27: 391-395.

Bancroft, J.D. and H.C. Cook, 1994. Manual of Histological Techniques and their Diagnostic Application. Churchill Livingstone, London, pp: 457.

Barlas, N., 1997. A pilot study of heavy metal concenration in various environments fishes in the upper Sakarya River Basin, Turkey. Environ. Toxicol., 14: 367-373.

Bernhard, M., 1976. Manual of methods in aquatic environment research. FAO Fisheries Techinical Paper Firi / T 158. Rome, Italy, pp: 1-153.

Bhagwant, S. and K.B. Elahee, 2002. Pathologic gill lesions in two edible lagoon fish species, Mulloidichtys flavolineatus and Mugil cephalus, from the bay of poudre d'or, mauritis. Western Indian Ocean J. Mar. Sci., 1: 35-42.

Birchall, J.D., C. Exley, J.S. Chappell and M.J. Phillips, 1989. Acute toxicity of aluminium to fish eliminated in silicon-rich acid waters. Nature, 338: 146-148.

Carrasco, K., K.L. Tilbury and M.S. Myers, 1990. Assesment of the piscine micronucleus test as in situ biological indicator of chemical contaminant effects. Can. J. Fish Aquat. Sci., 47: 2123-2136.

Cavas, T. and S. Ergene-Gozukara, 2003. Evaluation of the genotoxic potential of lambda-cyhalotrin using nuclear and nucleolar biomarkers on fish cells. Mutat. Res., 534: 93-99.

Davies, C.A., K. Tomlinson and T. Stephenson, 1991. Heavy metals in River Tees estuary sediments. Environ. Technol., 12: 961-972.

Ergene, S., T. Cavas, A. Celik, N. Koleli, F. Kaya and A. Karahan, 2007. Monitoring of nuclear abnormalities in peripheral erythrocytes of three fish species from the Goksu Delta (Turkey): Genotoxic in relation to water pollution. Ecotoxicology, 16: 385-391.

FAO/WHO, 1989. Evaluation of certain food additives and the contaminants mercury lead and cadmium. WHO Technical Report, Series No. 505.

Fabbri, E., A. Capuzzo and T.W. Moon, 1998. The role of circulating catecholamines in the regulation of fish metabolism: An overview. Comp. Biochem. Physiol. C Pharmacol. Toxicol. Endocrinol., 120: 177-192.

Figueiredo-Fernandes A., J.V. Ferreira-Cardosa, S. GarciaSantos, S.M. Monteiro, J. Carrola, P. Matos and A. Fontainhas-Fernandes, 2007. Histopathological changes in liver and gill epitelium of Nile tilapia, Oreochromis niloticus, exposedto waterborne copper. Pesq. Vet. Bras., 27: 103-109.
Geeraerts, C. and C. Belpaire, 2009. The effects of contaminants in European eel: A review. Ecotoxicology, 19: 239-266.

Gonzales, A.E., M.T. Rodriguez, J.C.J. Sanchez, A.J.F. Espinosa and F.J.B. De La Rosa, 2000. Assessment of metals in sediments in a tributary of guadalquivir river (Spain), heavy metal partitioning and relation between the water and the sediment system. Water Air Soil Pollut., 121: 11-29.

Grisolia, C.K. and C.M.T. Cordeiro, 2000. Variability in micronucleus induction with different mutagens applied to several species of fish. Genet. Mol. Biol., 23: 235-239.

Grisolia, C.K. and F.L.R.M. Starling, 2001. Micronuclei monitoring of fishes from Lake Paranoa under influence of sewage treatment plant discharges. Mutat. Res., 491: 39-44.

Gulmini, M., G. Ostacoli and V. Zelano, 1994. Comparison between microware and conventional heating procedures in tessiers extractions of calcium, copper, iron and manganese in a lagoon sediment. Analyst, 119: 2075-2080.

Gumgum, B., E. Unlu, Z. Tez and Z. Gulsun, 1994. Heavy metal pollution in water, sediment and fish from the Tigris River in Turkey Chemosphere, 29: 111-116.

Hammond, P.B. and R.P. Beliles, 1980. Metals. In: Toxicology: The Basic Science of Poisons, Doull, J., C.D. Klassen and M.O. Amdur (Eds.). Macmillan Publishing Co. Inc., New York, pp: 409-467.

Heddle, J.A., M.C. Cimino, M. Hayashi, F. Romagna and M.D. Shelby et al., 1991. Micronuclei as an index of cytogenetic damage: Past, present and future. Environ. Mol. Mutag., 18: 277-291.

Jacques, B., 1990. Effects of heavy metals on eels, Anguilla sp. Aquat. Living Resour., 3: 131-141.

Jiraungkoorskul, W., S. Sahapong and K. Niwat, 2007. Toxicity of copper in butterfish (Pronotus triacanthus): Tissues accumulation and ultrastructural changes. Environ. Toxicol., 22: 92-100.

Kalay, M. and M. Canli, 2000. Elimination of essential (Cu and $\mathrm{Zn}$ ) and non-essential $(\mathrm{Cd}$ and $\mathrm{Pb})$ metals from tissue of a freshwater fish, Tilapia zilli. Turk J. Zool., 24: 429-436.

Klavins, M., A. Briede, V. Rodinov, I. Kokorite, E. Parele and I. Klavina, 2000. Heavy metals in river of Lativa. Sci. Total Environ., 262: 175-183.

Koca, S., Y.B. Koca, S. Yildiz and B. Gurcu, 2008. Genotoxic and Histopathological effects of water pollution on two fish species, Barbus capito pectoralis and Chondrostoma nasus in the Buyuk Menderes River, Turkey. Biol. Trace Element Res., 122: $276-291$ 
Koca, Y.B., S. Koca, S. Yildiz, B. Gürcü, E. Osanc, O. Tuncbas and G. Aksoy, 2005. Investigation of histopathological and cytogenetic effects on Lepomis gibbosus (Pisces: Perciformes) in the Cine stream (Aydin/Turkey) with determination of water pollution. Environ. Toxicol., 20: 560-571.

Leland, H.V., S.N. Luorna and D.J. Wilkes, 1978. Heavy metals and related trace elements. J. Water Pollut. Control Federat., 50: 1469-1514.

Linde, A.R., S. Sanchez-Galan and E. Garcia-Vazquez, 2004. Heavy metal contamination of European eel (Anguilla anguilla) and brown trout (Salmo trutta) caught in wild ecosystems in Spain. J. Food Prot., 67: 2332-2336.

Mallatt, J., 1985. Fish gill structural changes induced by toxicants and other irritants: A statistical review. Can. J. Fish. Aquat. Sci., 42: 630-648.

Mason, A.F., C.C. Cerqueira and M.N. Fernandez, 2002. Gill cellular changes induced by copper exposure in the South American tropical freshwater fish Prochilodus scrofa. Environ. Res., 88: 52-63.

Matsumoto, S.T., M.S. Mantovani, M.I.A. Malaguttii, A.L. Dias, I.C. Fonseca and M.A. Marin-Morales, 2006. Genotoxicity and mutagenicity of water contaminated with tannery effluents, as evaluated by the micronucleus test and comet assay using the fish Oreochromis niloticus and chromosome aberrations in onion root-tips. Genet. Mol. Biol., 29: 1415-4757.

Melgar, M.J., M. Perez, M.A. Garcia, J. Alonso and B. Miguez, 1997. The toxic and accumulative effects of short term exposure to cadmium in rainbow trout (Oncorhnynchus mykiss). Vet. Hum. Toxicol., 39: 79-83.

Nero, V., A. Farwell, A. Lister, G. van der Kraak and L.E. Lee et al., 2006. Gill and liver histopathological changes in yellow perch (Perca flavescens) and goldfish (Carassius auratus) exposed to oil sands process-affected water. Ecotoxicol. Environ. Safety, 63: 365-377.

Oliveira Ribeiro, C.A., Y. Vollaire, A. Sanchez-Chardi and H. Roche, 2005. Bioaccumulation and the effects of organochlorine pesticides, $\mathrm{PAH}$ and heavy metals in the eel (Anguilla anguilla) at the Camargue Nature Reserve, France. Aquacul. Toxicol., 74: 53-69.

Olojo, E.A.A., K.B. Olurin, G. Mbaka and A.D. Oluwemimo, 2005. Histopathology of the gill and liver tissues of the African catfish Clarias gariepinus exposed to lead. Afr. J. Biotechnol., 4: 117-122.

Ortiz, J.B., M.L. Gonzales and C. Sarasquete, 1999. Quantification and histopathological alterations produced by sublethal copper concentration in Fundulus heteroclitus. Ciencias Marinas, 25: 119-143.
Parlak, H., A. Cakir, M. Boyacioglu and O.C. Arslan, 2006. Heavy metal deposition in sediments from the delta of the Gediz River(Western Turkey): A preliminary study. EU. J. Fish. Aquat. Sci., 23: 445-448.

Randi, A.S., J.M. Monserrat, E.M. Rodriguez and L.A. Romano, 1996. Histopathological effects of cadmium on the gills of the freshwater fish, Macropsobrycon uruguayanae Eigenmann (Pisces, Atherinidae). J. Fish. Dis., 19: 311-322.

Rodriguez-Cea, A., F. Ayllon and E. Garcia-Vazquez, 2003. Micronucleus test in freshwater fish species: An evaluation of its sensitivity for application in field surveys. Ecotoxicol. Environ. Safety, 56: 442-448.

Sanchez-Galan S. A.R. Linde, F. Ayllon and E. GarciaVazquez, 2001. Induction of micronuclei in Eel (Anguilla anguilla) by heavy metals. Ecotoxicol. Environ. Sef., 49: 139-143.

Sanchez-Galan, S., A.R. Linde, J.I. Izquierdo and E. GarciaVazquez, 1998. Micronuclei and fluctuating asymmetry in brown trout (Salmo trutta): Complementary methods biomonitor freshwaters ecosystems. Mutat. Res., 412: 218-225.

Segner, H., 1998. Isolation and primary culture of teleost hepatocytes. Comp. Biochem. Physiol. A Mol. Integrative Physiol., 120: 71-81.

Shephard, K.L., 1994. Functions for fish mucus. Rev. Fish Biol. Fish., 4: 401-429.

Singh, M., 2001. Heavy metal pollution in freshly deposited sediments of the Yamuna River (the Ganges river tributary): A case study from Delhi and Agra urban centres, India. Environ. Geol., 40: 664-671.

Solomons, W. and U. Forstner, 1984. Metals in the Hydrocycle. Springer, Berlin, pp: 653.

Srivastava, S.K., V.K. Gupta and D.A. Mohan, 1994. Status of some toxic heavy metal ions in the upper reaches of river Ganges. J. Indian Chem. Soc., 71: 29-34.

Thophon, S., M. Kruatrachue, E.S. Upatham, P. Pokethitiyook, S. Sahaphong and S. Jaritkhuan, 2003. Histopathological alterations of white seabass, Lates calcarifer, in acute and subchronic cadmium exposure. Environ. Pollut., 121: 307-320.

Triebskorn, R., I. Telcean, H. Casper, A. Farkas and C. Sandu et al., 2008. Monitoring pollution in River Mures, Romania, part II: Metal accumulation and histopathology in fish. Environ. Monit. Assess., 141: 177-188.

Tuckett, F. and G. Morris-Kay, 1988. Alcian blue staining of glycosaminoglycans in embrionic material: Effect of different fixatives. Histochem. J., 20: 174-182. 
Usero, J., C. Izquierdo, J. Morillo and I. Gracia, 2003. Heavy metals in fish (Solea vulgaris,Anguilla anguilla and Liza aurata) from salt marshes on the southern Atlantic coast of Spain. Environ. Int, 29: 949-956.

Veena, B., C.K. Radhakrishnan and J. Chacko, 1997. Heavy metal induced biochemicale effets in an estuarine teleost. Indian J. Mar. Sci., 26: 74-77.

Vinodhini R. and M. Narayanan, 2009. Cytoprotective effect of Nelumbo nucifera and Aegle marmelos in common carp (Cyprinus carpio L.) exposed to heavy metals. IJIB, 7: 124-129.

Wendelaar, B.S.E., 1997. The stress response in fish. Physiol. Rev., 77: 591-625.

Wood, C.M., S.P. Kelly, B. Zhou, M. Fletcher, M. O'Donnell, B. Eletti and P. Part, 2002. Cultured gill epithelia as models for the freshwater fish gill. Biochim. Biophys. Acta, 1566: 72-83.
Yilmaz, F., 2009. The comparison of heavy metal concentrations ( $\mathrm{Cd}, \mathrm{Cu}, \mathrm{Mn}, \mathrm{Pb}$, and $\mathrm{Zn})$ in tissues of three economically important fish (Anguilla anguilla, Mugil cephalus and Oreochromis niloticus) Inhabiting Koycegiz Lake-Mugla (Turkey). Turk. J. Sci. Technol., 4: 7-15.

Zuniga, G., O. Torres-Bugarin, M.P. Ramirez-Munoz, A. Ramos and E. Fanti-Rodriguez et al., 1996. Spontaneous micronuclei in peripheral blood erythrocytes from 35 mammalian species. Mutat. Res., 369: 123-127.

Zuniga-Gonzalez, G., O. Torres-Bugarin, J. Luna-Aguirre, A. Gonzalez-Rodriguez and A. Zamora-Perez et al., 2000. Spontaneous micronuclei in peripheral blood erythrocytes from 54 animal species (mammals, reptiles and birds): Part two. Mutat. Res., 467: 99-103. 